\title{
Total work and gender: facts and possible explanations
}

\author{
Michael Burda • Daniel S. Hamermesh • \\ Philippe Weil
}

Received: 14 September 2010 / Accepted: 1 February 2012 /

Published online: 3 March 2012

(C) The Author(s) 2012. This article is published with open access at Springerlink.com

\begin{abstract}
Time-diary data from 27 countries show a negative relationship between GDP per-capita and gender differences in total work-for pay and at home. In rich non-Catholic countries, men and women average about the same amount of total work. Survey results show scholars and the general public believe that women work more. Widespread average equality does not arise from gender differences in the price of time, intra-family bargaining or spousal complementarity. Several theories, including ones based on social norms, might explain these findings and are consistent with evidence from the World Values Surveys and microeconomic data from Australia and Germany.
\end{abstract}

Keywords Time use $\cdot$ Gender differences $\cdot$ Household production

\begin{abstract}
Responsible Editor: Alessandro Cigno
Humboldt-Universität zu Berlin, CEPR and IZA; University of Texas at Austin, Maastricht University, IZA and NBER; OFCE, Sciences-Po, Université Libre de Bruxelles and CEPR. We thank Olivier Blanchard, Tito Boeri, Micael Castanheira, Deborah Cobb-Clark, Raquel Fernández, Georg Kirchsteiger, Christopher Pissarides, participants in seminars at several universities and conferences for helpful comments, several anonymous referees, and Rick Evans and Juliane Scheffel for their expert research assistance.
\end{abstract}

\section{Burda}

Fakultät der Wirtschaftswissenschaft, Humboldt-Universität zu Berlin, 10178 Berlin, Germany

D. S. Hamermesh $(\varangle)$

Department of Economics, University of Texas at Austin, Austin, TX 78712, USA

e-mail: hamermes@eco.utexas.edu

P. Weil

Observatoire Français des Conjunctures Economiques, 69 Quai d'Orsay, 75007 Paris, France 
JEL Classification $\mathrm{J} 22 \cdot \mathrm{J} 16 \cdot \mathrm{D} 13$

\section{Introduction}

Men engage in more market work than women. What have not been thoroughly examined, and indeed have been almost ignored by economists, are gender differences in the total amount of work-the sum of work in the market and at home. Despite the obvious importance of looking more closely at how people spend their non-work time, relatively little attention has been paid to describing its patterns and examining its determinants. A few studies have considered how the price of time affects the distribution of non-work time (Biddle and Hamermesh 1990; Kalenkoski et al. 2009); and Freeman and Schettkat (2005) have examined possible trade-offs between market and non-market work in a few countries. This line of inquiry has been limited by the relative paucity of available data sets. This absence of data has begun to change, and that change enables us to examine gender differences in the allocation of total work time.

The issue of gender differences in time use is important for a number of reasons. First, because the amount of work (and thus the utility from leisure) is one of the crucial arguing points in the "gender wars," simply discovering new facts about it is important. Second, the determinants of those facts allow inferring how patterns of work by gender change as economies develop. Third, by generating new explanations for patterns of gender differences in the amount of total work, we may provide an impetus for using similar theories to examine other differences in the allocation of time. Finally, these facts and the related theoretical discussion impose restrictions on a variety of economic models.

Our purposes here are to document in much greater detail a fact that has been essentially ignored by economists and that appears unknown to the public, and to offer and test some explanations for it. In the next section, we describe what we mean by market and household work and examine the gender breakdown of work at home and in the market using time-diary data from 27 countries. Whether the facts that we adduce in Section 2 are novel, and whether they are already widely known, are examined in Section 3. Section 4 considers some possible explanations of our findings and indicates which ones seem inconsistent with aggregate data. Section 5 examines some microeconometric evidence. The end result is a variety of facts and the ability to rule out some explanations for them. Section 6 indicates how these considerations might be used to inform how we model a variety of economic behavior.

\section{Gender differences in market and home work}

In order to examine gender differences in work we need to devise general rules that allow activities to be classified as work. We follow standard practice, defining market work as time spent for pay (or in unpaid household production 
for the market). We assume people would not be working the marginal hour in the market if they were not paid. In the economics literature market work has generally been treated as the complement of the aggregate of all activities outside the market-implicitly all uses of non-market time have been assumed to be aggregable.

Household work includes those activities that satisfy the third-party rule (Reid 1934) that substituting market goods and services for one's own time is possible. We define total work as the sum of time spent in market work and household production. Note that we do not and cannot examine gender differences in the consumption value of the average or marginal minute of market or household production; all we do here is estimate, and then try to explain differences in the total amount of time spent in productive activities.

Throughout this initial empirical section we define the aggregates of activities as similarly as possible across the countries under study. Respondents in these studies are given a time-diary for one or more recent days and asked to account for all time during that day. The respondent either works from a set of codes indicating specific activities, or the survey team codes the descriptions into a pre-determined set of categories.

Time-diaries have the virtue of forcing respondents to report a time allocation that adds to $24 \mathrm{~h}$ in a day. Also, unlike retrospective data about last year's or even last week's work time, while the time-diary information is necessarily based on recall, the recall period is only one day. The shorter recall period and the implicit time-budget constraint suggest that information on market work from time diaries is likely to be more reliable than the recall data on time use from standard household surveys. Most crucially, time diaries provide information on non-market activities that is generally unavailable in laborforce surveys.

The aggregates from Australia, Germany, Italy, the Netherlands, Spain, the United States and Israel used here represent our own calculations from micro data. We added aggregations based on published summaries of recent timediary studies from seven wealthy European countries (Belgium, Denmark, France, Finland, Sweden, the United Kingdom, and Norway) and three transition countries (Estonia, Hungary and Slovenia) from Aliaga and Winqvist (2003); from various published summaries describing the results of time-diary studies conducted since 1992 in Canada, Ireland, Japan and New Zealand, and Benin, Madagascar, Mauritius and South Africa (from Blackden and Wooden 2006), and from Mexico and Turkey. ${ }^{1}$

Definitions of total work are shown in the Appendix. Obviously, they are not identical across countries-but they are identical across gender within country. We cannot prove the absence of a systematic bias in the aggregations of results in each diary toward counting as work activities those performed

\footnotetext{
${ }^{1}$ While a few of the underlying micro data sets are available, most are not, thus necessitating our reliance on published sub-aggregates in constructing the aggregates of total work. These countries represent the entire set for which we could find appropriate data.
} 


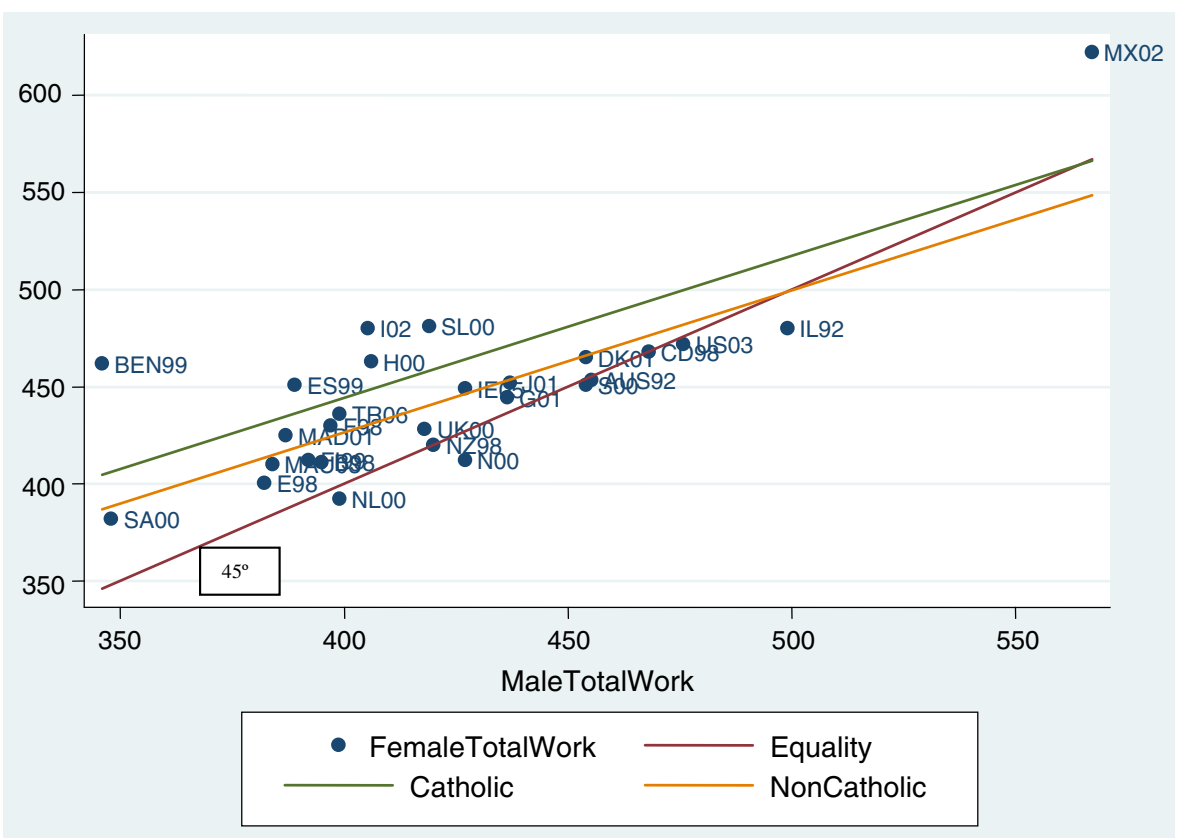

Fig. 1 Female total work against male total work, 27 countries (non-Catholic (upper parallel line), Catholic (lower parallel line), equality of total work $\left(45^{\circ}\right.$-line)). The country abbreviations are listed in the Appendix

especially by one gender or the other; but for our cross-country results to be biased would require systematic errors that are the same in most countries' methods of categorizing work activities.

Among the 27 countries, women's (unweighted) average total work is $446.4 \mathrm{~min}$ per day (s.e. $=8.6)$, men's is $421.7 \mathrm{~min}($ s.e. $=8.9)$. Women's total work significantly exceeds men's in this sample, albeit not by a huge amount. If we restrict the sample to the 14 wealthy non-Catholic countries (2002 real GDP/capita above $\$ 15,000$, from Heston et al. 2006), the averages are 440.1 $($ s.e. $=7.4)$ and $431.4($ s.e. $=7.5)$ respectively, a statistically insignificant gender difference in total work. ${ }^{2}$ We refer to this striking outcome henceforth as the iso-work phenomenon. This finding implies that there also is gender equality in the total of non-work time consumed in rich nations that lack a Catholic cultural background.

The scatter diagram in Fig. 1 compares men's and women's total work in the 27 countries. The steepest line shows what women's total work would be if it were identical to men's. A regression relating women's to men's total work and

\footnotetext{
${ }^{2}$ We classify Belgium, Spain, France, Italy, Ireland and Mexico as Catholic countries, as they are the only ones with large, at least nominally Catholic majorities.
} 


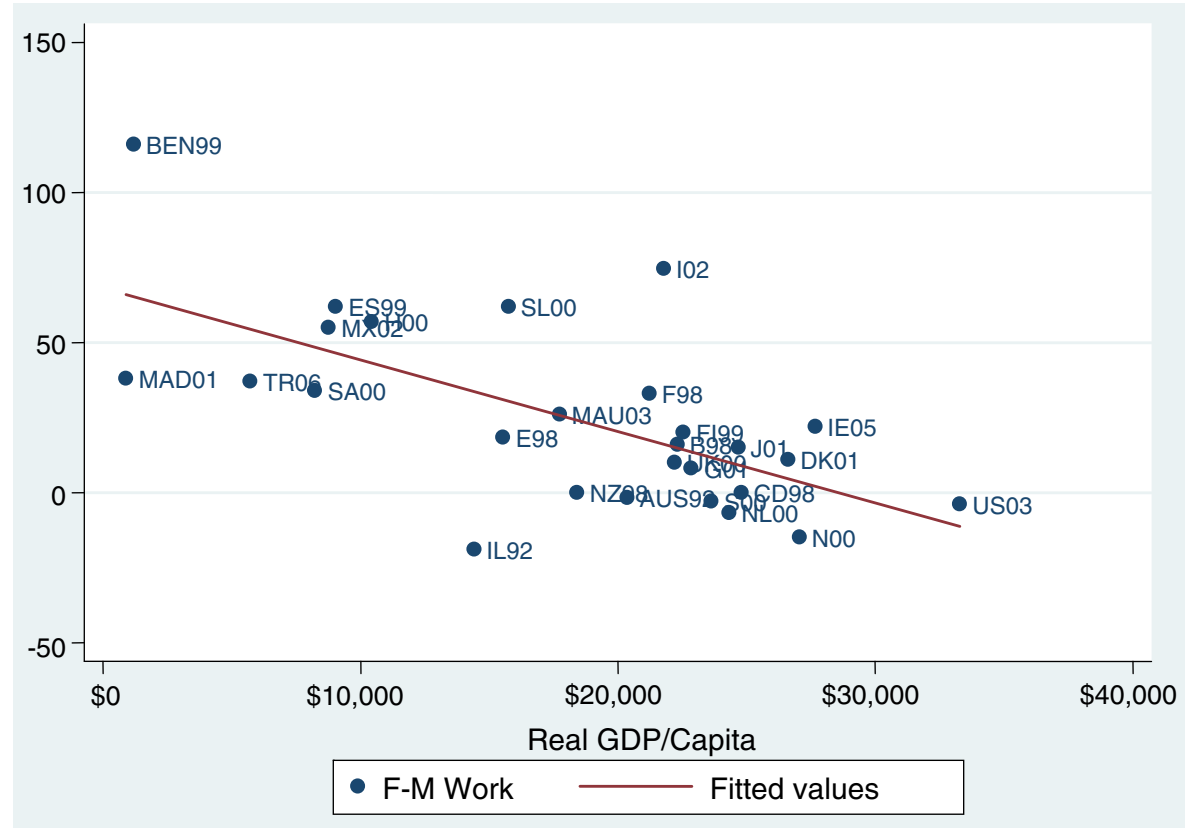

Fig. 2 Female-male total work and real GDP per-capita, 27 countries. $\mathrm{F}-\mathrm{M}$ Work $=68.16-2.39(0.56)$ RealGDP/Capita; Adj. $R^{2}=0.394$

including an indicator for religious background (equaling one in six countries) yields:

$$
\begin{aligned}
\text { FemaleTotalWork }= & 134.05(51.54)+0.73(0.12) \text { MaleTotalWork } \\
& +17.72(13.36) \text { Catholic, } \mathrm{N}=27, \text { Adj. } R^{2}=0.590 .
\end{aligned}
$$

(The regression line through the non-Catholic points is the lower of the two parallel lines in Fig. 1.) We reject the hypotheses that the intercept is zero and that the slope on MaleTotalWork is one, as well as the joint hypothesis. ${ }^{3}$ Nonetheless, the slope of the relationship between total work by gender is economically not that much different from one, and the averages for rich nonCatholic countries do not differ statistically or economically.

Figure 2 shows a scatter of the difference in average minutes per day of female over male total work time and real GDP/capita and a line fitting these points. It suggests either that economic development is highly positively correlated with gender equality of total work or that today's rich nonCatholic countries have always had a different culture along this dimension. Furthermore, the relationship appears to be nonlinear, with gender equality being approached or even reached at a sufficiently high level of personal income.

\footnotetext{
${ }^{3}$ The statistic testing the joint hypothesis is $F(2,24)=8.18, p=0.002$.
} 
Based on these results we cannot claim that gender equality in total work holds at all times and places. It does not hold in middle-or lower-income countries today or in predominantly Catholic countries. Perhaps if more data were available on still other countries, the conclusion might change; but based on all the available evidence the results suggest strongly that iso-work characterizes average household behavior and labor markets in rich non-Catholic countries. Moreover, the cross-section evidence suggests that iso-work is approached as real incomes rise.

\section{Novelty and knowledge}

The iso-work fact has been hinted at by several sociologists. Robinson and Godbey (1999) show that it describes the average of (recall and time-diary) data from 14 countries from the 1980s and early 1990s; and Gershuny (2000) shows that it roughly characterizes the two averages over a similar but still smaller sample of data sets covering the 1960s through the mid-1990s. No study has demonstrated it using data sets that were as well-harmonized as those that we used here, nor has one shown how closely it describes average outcomes in individual countries.

While iso-work is not new to the sociology literature, it appears not to have been studied by economists. The difficulty, however, is that it has been swamped by claims in widely circulated ethnographic studies (Hochschild 1997, and earlier work) based on a few households that women's total work significantly exceeds men's. Indeed, even sociologists who demonstrated it (e.g., Mattingly and Bianchi 2003, for the United States, and Bittman and Wajcman 2000, for several countries), downplayed it to focus on claims that women's work is more onerous than men's and that women's leisure provides less pleasure.

Whether the possibility of iso-work is well known among economists, other social scientists and the general public is unclear. To examine this issue, we designed a survey that asked the following question:

"We know that American men (ages 20-75) on average work more in the market than do American women. But what is the difference between men's TOTAL WORK (in the market and on anything that you might view as work at home) and that of women? Without consulting any books, articles or raw data, PLEASE PUT AN X NEXT TO THE LINE BELOW THAT YOU BELIEVE TO BE THE CLOSEST APPROXIMATION TO THE CURRENT SITUATION IN THE US."

Respondents were allowed nine possible responses, ranging from a $25 \%$ excess of female total work, to symmetry around equality, to a $25 \%$ excess of male total work.

In August 2006 we emailed this survey to three groups: (1) 663 labor economists affiliated with a worldwide network of such researchers. The survey distinguished respondents who had spent at least six months in the U.S. from 
Table 1 Expert and other opinion about men's and women's total work (percent distributions)

\begin{tabular}{|c|c|c|c|c|c|}
\hline Men work: & $\begin{array}{l}\text { Labor } \\
\text { economists } \\
\text { familiar } \\
\text { with US }\end{array}$ & $\begin{array}{l}\text { Labor } \\
\text { economists } \\
\text { unfamiliar } \\
\text { with US }\end{array}$ & $\begin{array}{l}\text { Elite } \\
\text { macro and } \\
\text { public finance } \\
\text { economists }\end{array}$ & $\begin{array}{l}\text { Sociology } \\
\text { faculty and } \\
\text { graduate } \\
\text { students }\end{array}$ & $\begin{array}{l}\text { Economics } \\
\text { principles } \\
\text { students }\end{array}$ \\
\hline At least $10 \%$ less & 41.8 & 50.7 & 44.8 & 60.0 & 43.6 \\
\hline $5 \%$ less & 11.7 & 11.3 & 10.5 & 11.7 & 12.8 \\
\hline Differ by less than $2.5 \%$ & 25.8 & 25.4 & 34.2 & 20.0 & 23.1 \\
\hline $5 \%$ more & 6.1 & 4.9 & 3.9 & 1.7 & 9.2 \\
\hline At least $10 \%$ more & 14.6 & 7.7 & 6.6 & 6.6 & 11.3 \\
\hline$N$ & 213 & 142 & 76 & 60 & 445 \\
\hline $\begin{array}{l}t \text { statistic on binomial if } \\
\text { "equal" answers are } \\
\text { split evenly }\end{array}$ & 5.47 & 6.73 & 4.08 & 6.08 & 8.98 \\
\hline RESPONSE RATE & 0.535 & & 0.298 & 0.286 & 0.873 \\
\hline
\end{tabular}

Responses to the question: "We know that American men (ages 20-75) on average work more in the market than do American women. But what is the difference between men's TOTAL WORK (in the market and on anything that you might view as work at home) and that of women? Without consulting any books, articles or raw data, PLEASE PUT AN X NEXT TO THE LINE BELOW THAT YOU BELIEVE TO BE THE CLOSEST APPROXIMATION TO THE CURRENT SITUATION IN THE US.”

those who had not; (2) 255 elite macro and public finance economists, members of a mostly American network of such researchers; and (3) 210 faculty members and graduate students in a leading American sociology department. The first and third groups received follow-up emails three weeks after the initial survey. Also, early in September 2006 we asked the same question of 533 students in an introductory microeconomics class. Using the information on location in the first group, we thus have five separate sets of responses.

The results are shown in Table 1, with the categories greater than or equal to $10 \%$ or less than or equal to $-10 \%$ combined for presentational ease. The majority of respondents in each group believe that American women perform at least 5\% more total work than men. Assigning half the respondents who state that there is equality to this category, in all samples we easily reject the null hypothesis that the proportions stating that men work less or women work less are equal. ${ }^{4}$

Despite the apparent gender equality of total work in most rich countries, all groups considered were unaware of this. It may be the case that most people are in fact aware of the underlying differences while our samples are simply unrepresentative; and, as is always true with eliciting information about beliefs, perhaps the respondents to our surveys were thinking about something other than the sheer quantity of work-perhaps how onerous it is. Nonetheless, this evidence suggests as strongly as survey evidence on subjective beliefs can that people believe women's total work exceeds men's in rich countries.

\footnotetext{
${ }^{4}$ Even if we were to assign all those stating that there is equality to the "men work more" group, this null hypothesis would still be rejected in some of the samples.
} 


\section{Explaining the phenomenon: which theories can or cannot?}

\subsection{Market-based forces}

Assuming iso-work is a fair description of behavior in many rich countries, it is natural to try to explain it as the outcome of market forces that differ across countries but present women and men within each country with similar economic choices. This is a difficult task. To start, economic theory would predict iso-work as a market outcome if men and women: (1) had the same preferences over work and leisure-or at least could be approximated by the same representative agent; (2) faced the same market wage, net of taxes and other costs of participation, and (3) had identical productivity in home production. To deviate from this set of implausible symmetry conditions and still obtain iso-work as an equilibrium outcome, additional restrictions on preferences, prices and endowments are necessary. For example, if goods produced at home are perfect substitutes for market goods, and the representative man and woman have identical Cobb-Douglas preferences over leisure (and no differential disutility from hours supplied in either type of work), then the combined supply of hours to market and home production is constant and identical across gender. Because these assumptions are hardly more plausible than the symmetric and symmetric-and-equal assumptions, isowork as a market outcome seems more likely a coincidence than a central tendency across economies robustly predicted by theory.

The task becomes even more difficult when we try to explain deviations from iso-work in developing countries and their tendency to disappear as economies develop. Assuming substitution effects dominate income effects, economic theory predicts that a rise in women's relative wage (i.e., a decline in the gender wage gap) will lead to more work in the market by women relative to men. The impact of this increase on the relative amount of home work should be in the opposite direction, so that the effect of a change in the gender gap on the relative amounts of total work is ambiguous. Unless, however, additional market work is offset one-for-one by reduced home work, a rise in the female relative wage should raise women's relative total work.

To examine this possibility, we use estimates of the difference between the logarithms of the medians of the distributions of males' and females' wages produced by Polachek and Xiang (2009) for 19 of the 27 countries used here. The first two columns in Table 2 present least-squares estimates of equations describing female-male differences in market and total work across countries as functions of the gender wage gap. The results on market work are consistent with an upward-sloping relative supply curve of labor. The market work effect, however, dominates the household work effect, so that we find that the femalemale gap in total work is also positively related to the female-male wage ratio.

These findings are not affected by the inclusion of real GDP per-capita, as the estimates in Columns (3) and (4) show, nor are they affected by adding the indicator for Catholic countries. That the GDP variable is only marginally statistically significant, whereas Fig. 2 suggested a strong negative relationship 
Table 2 Impact of the gender pay gap on the gender total work (minutes per day)

\begin{tabular}{|c|c|c|c|c|c|c|}
\hline $\begin{array}{l}\text { Dep. var., female- } \\
\text { male total work }\end{array}$ & $\begin{array}{l}\text { (1) Market } \\
\text { work }\end{array}$ & $\begin{array}{l}\text { (2) Total } \\
\text { work }\end{array}$ & $\begin{array}{l}\text { (3) Market } \\
\text { work }\end{array}$ & $\begin{array}{l}\text { (4) Total } \\
\text { work }\end{array}$ & $\begin{array}{l}\text { (5) Market } \\
\text { work }\end{array}$ & $\begin{array}{l}(6) \text { Total } \\
\text { work }\end{array}$ \\
\hline $\begin{array}{l}\log (\text { female/male } \\
\text { wage })^{\mathrm{a}}\end{array}$ & $\begin{array}{l}135.5 \\
(73.02)\end{array}$ & $\begin{array}{l}44.0 \\
(38.54)\end{array}$ & $\begin{array}{l}182.8 \\
(66.96)\end{array}$ & $\begin{array}{l}23.47 \\
(37.42)\end{array}$ & $\begin{array}{r}162.68 \\
(71.71)\end{array}$ & $\begin{array}{c}55.00 \\
(32.34)\end{array}$ \\
\hline $\begin{array}{l}\text { Real GDP } \\
\text { per-capita }(\$ 000)^{\mathrm{b}}\end{array}$ & & & $\begin{array}{c}4.38 \\
(1.78)\end{array}$ & $\begin{array}{l}-1.90 \\
(1.00)\end{array}$ & $\begin{array}{l}3.98 \\
(1.92)\end{array}$ & $\begin{array}{l}-1.20 \\
(0.87)\end{array}$ \\
\hline Catholic & & & & & $\begin{array}{l}-17.22 \\
(26.07)\end{array}$ & $\begin{array}{l}33.78 \\
(11.76)\end{array}$ \\
\hline $\begin{array}{l}\text { Adj. } R^{2} \\
N=19\end{array}$ & 0.120 & 0.017 & 0.321 & 0.149 & 0.293 & 0.423 \\
\hline
\end{tabular}

Standard errors in parentheses

${ }^{\mathrm{a} F r o m}$ Polachek and Xiang (2009)

${ }^{b}$ From Heston et al. (2006)

with a diminishing slope, arises from the exclusion of many of the poorer countries (for which relative wage data are unavailable). Despite the quality of the estimates, the equation in Column (6) describes below half of the variance in the gender difference in total work across countries. The difficulty is that in 14 of these 19 countries these differences are clustered within $5 \%$ of equality, while the gender wage gaps in these data range from 0.07 to 0.69. Something besides equality in relative wages or differences in per-capita incomes is causing the pervasive absence of gender differences in total work.

\subsection{Bargaining, matching and imitation within couples}

A different perspective on iso-work arises from the literature on household behavior (e.g., Lundberg and Pollak 1996). In this view, the gender wage gap reflects differences in bargaining power in the household, as it would be regardless of whether one views spouses' behavior as described by a unitary or a collective model. By this criterion, we should expect to observe men working relatively less in total when female-male relative pay is lower, if preferences over leisure are normal. ${ }^{5}$ The estimates in Table 2 imply the opposite result. Where one might infer that men have more bargaining power, as measured by relative wages, their total work is in fact greater.

A second possible explanation for some of these facts is that husbands and wives pay attention to each other's labor and leisure, and gender equality

\footnotetext{
${ }^{5}$ Consider a large class of models in which spouses derive utility from consumption, which is public and joint to the couple, and separable in leisure, which is the time-budget complement of total work time. The couple must produce a fixed amount of public consumption at home using a constant returns production function of each household member's time, without prejudice to the relative efficiency of the man or woman. Assume that the joint family decision is to maximize a weighted sum of utilities of the two household members. The solution to this two-stage problem is a labor supply rule which implies iso-work if and only if each utility weight equals the percentage deviation of the respective gender wage from its average. Thus the greater the excess of male over female wages, the lower men's total work relative to women's. See for example Knowles (2011).
} 
obtains at the means in rich countries because most adult men and women are married. An explicit test of the notion that gender iso-work is generated by husbands and wives focusing on each other's work effort as part of marriage comes from examining inter-household dispersion in the within-household gender total work gap using data on couples. This examination is not possible for the U.S. in 2003, so instead we use the much smaller 1985 U.S. Time Use Survey. We use averages over 3 days from the 2001/02 German data and over 2 days from the 1992 Australian survey.

Figures 3, 4 and 5 show frequency distributions of within-household differences between the average daily total work of wives and husbands in the U.S., Australia and Germany. While the distributions are symmetric around means of zero, the implied dispersion is large. Regressions within each country of the wife's total work time on the husband's explain only $9 \%$ of the variation in the U.S., 29\% of the variation in Australia and 35\% in Germany. We do find evidence of complementarity of spouses' total work (and thus of leisure), but most of the dispersion in intra-household differences in total work remains. ${ }^{6}$ This evidence is inconsistent with the assertion that the iso-work phenomenon stems from the alignment of behavior within a couple, perhaps not surprising given the demonstration by Cigno (2009) that iso-work could result from noncooperative equilibria, which are less likely within marriage. ${ }^{7}$

\subsection{Social norms}

Another possible coordination device that we explore here is a social norm for leisure that generates a form of interdependent utility among agents and serves as a focal point for the determination of total work. Social norms have been increasingly incorporated into economic models, and they provide important additional insights and modifications into how we view markets as operating (see Fernández 2010, for a discussion). In our context, peer pressure leading to a desire to conform to a common social norm for time allocation mutes market incentives and weakens the impact of individual tastes. As a result, time use becomes more similar across individuals. ${ }^{8}$ If the social norm is strong enough to drive agents to conform fully, we obtain the iso-work result suggested by the data. ${ }^{9}$

While there are many variations on the theme, models of social norms have the following common feature. Absent a social norm, consumers maximize

\footnotetext{
${ }^{6}$ See Hamermesh (2002) for evidence of the importance of both the quantitative and timing aspects of complementarity of spouses' market work.

${ }^{7} \mathrm{By}$ extension, it is also inconsistent with a model of matching and search in which total hours worked are chosen to increase the chances of a successful match.

${ }^{8}$ Social norms have been studied, among many others, by Akerlof (1980), Lindbeck et al. (1999) and Kooreman (2007).

${ }^{9}$ In this simple story, total conformity only occurs if the desire to conform is infinitely strong. The literature on conformity (e.g. Bernheim 1994) has sought ways to obtain identical behavior without assuming an infinite cost of deviation.
} 


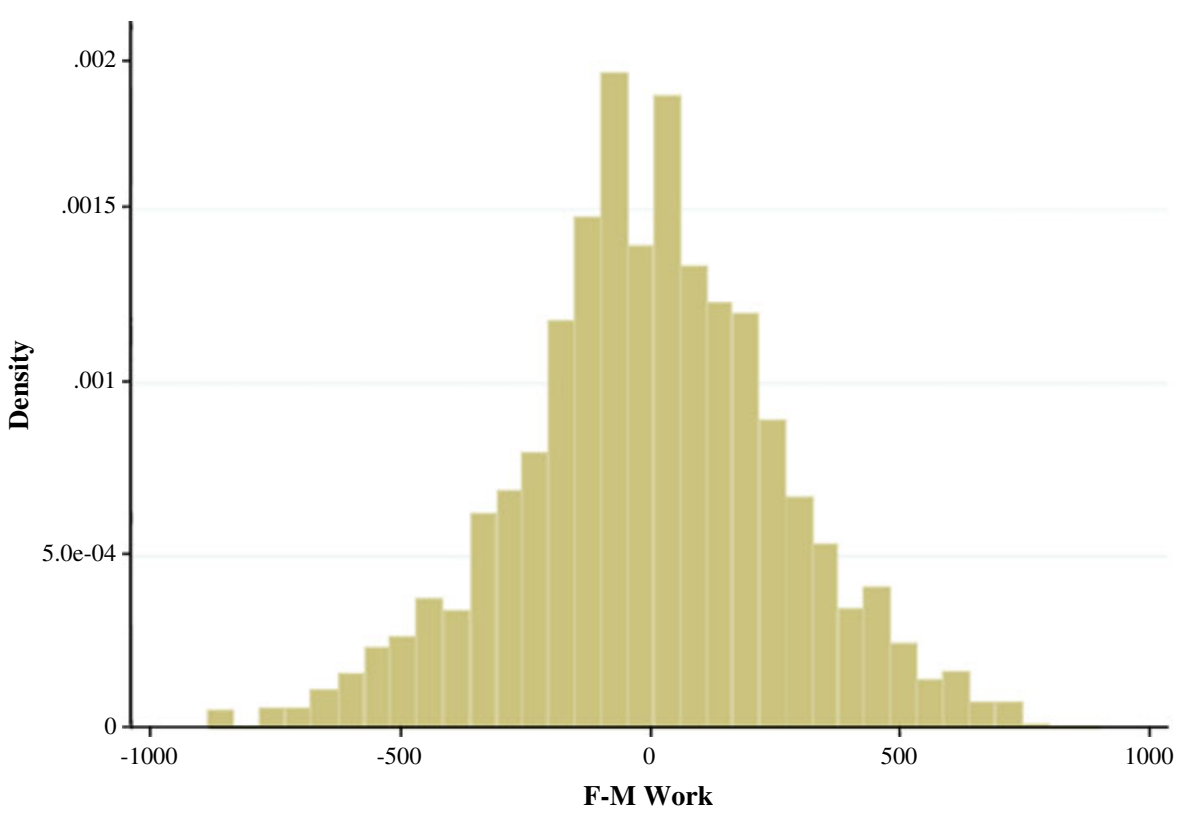

Fig. 3 Wife-husband difference in total work, United States 1985

utility given a standard budget constraint. Common behavior-as an average of that of members of a given and possibly endogenously determined groupconditions utility, so equilibrium enforces consistency of the individual's maximizing behavior with the group outcome. Deviations from the norm are costly.

A simple model of social norms is not sufficient to rationalize our observations. The empirical difficulty is that iso-work coexists with significant within-gender (and more generally within-group) heterogeneity of leisure. This is inconsistent with a simple single-norm account, because, as the penalty for deviating increases, the labor supply of each individual converges to a common, gender-neutral norm regardless of the wage. ${ }^{10}$ While a strong norm bridges the gap between male and female leisure, it also suppresses any withingender heterogeneity of leisure, which is a central feature of the data.

One way to avoid this feature is to allow multiple local social norms, unrelated to gender. ${ }^{11}$ Suppose each gender is stratified into social clusters that are defined by relative position in the wage distribution. For instance, males and females above their gender's median wage may share a common leisure norm, and there is another leisure norm below the median wage. Agents could just as well be clustered according to the color of their eyes, the month in which they are born, or the neighborhood where they live. The crucial assumption is

\footnotetext{
${ }^{10}$ This is also true if the sensitivity of leisure to gender wage differences differs by gender.

${ }^{11}$ For a detailed and formal exposition of this point, see Burda et al. (2007).
} 


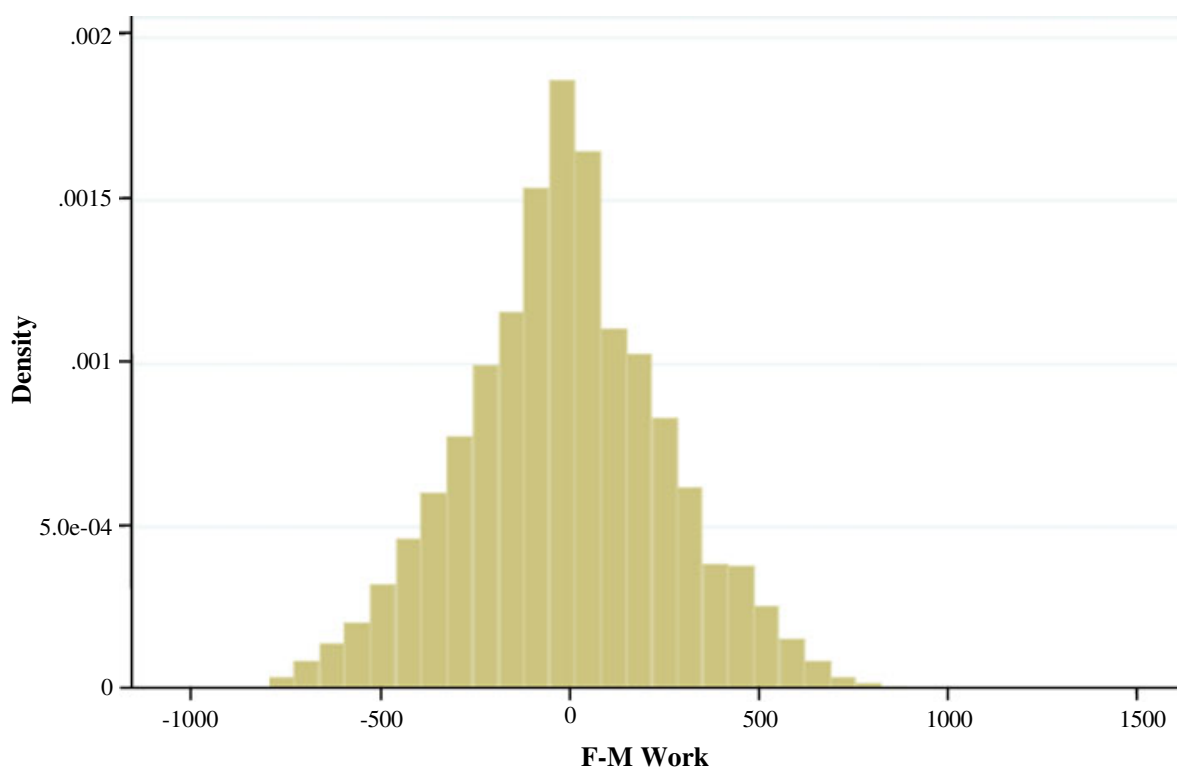

Fig. 4 Wife-husband difference in average total work per day, Australia 1992

that the clusters are defined by gender-neutral characteristics. ${ }^{12}$ In such models the greater the number of clusters or interacting groups, the more likely that iso-work can obtain.

The findings presented in Section 2 make it clear that total work does vary across countries, region and over time. Since one might rationalize iso-work by social norms by arguing that they serve as a coordination device between male and female total work, we must also explain how norms can vary. This is most simply done by endogenizing the norm.

A social norm theory of leisure can produce the negative relation between female-male differences in total work and GDP per-capita in various ways. The first relies on the link between economic development and increased gender neutrality of social reference groups. A model of social clusters can account for the reduction in the female-male total work difference as GDP per-capita grows, provided economic growth is positively correlated with the adoption of gender-neutral reference groups. Suppose that at low income levels there are two leisure reference groups: one for men, and one for women. This might be due to tastes for discrimination, for example, which are

\footnotetext{
${ }^{12} \mathrm{By}$ contrast, social leisure norms defined in terms of the position of the wage above or below some arbitrary levels (i.e., a leisure norm for "high" wage males and females, another one for "low" wage ones) will in general be gender-biased, as the proportions of males and females adopting a given norm will differ unless the separating levels happen to coincide with median wages.
} 


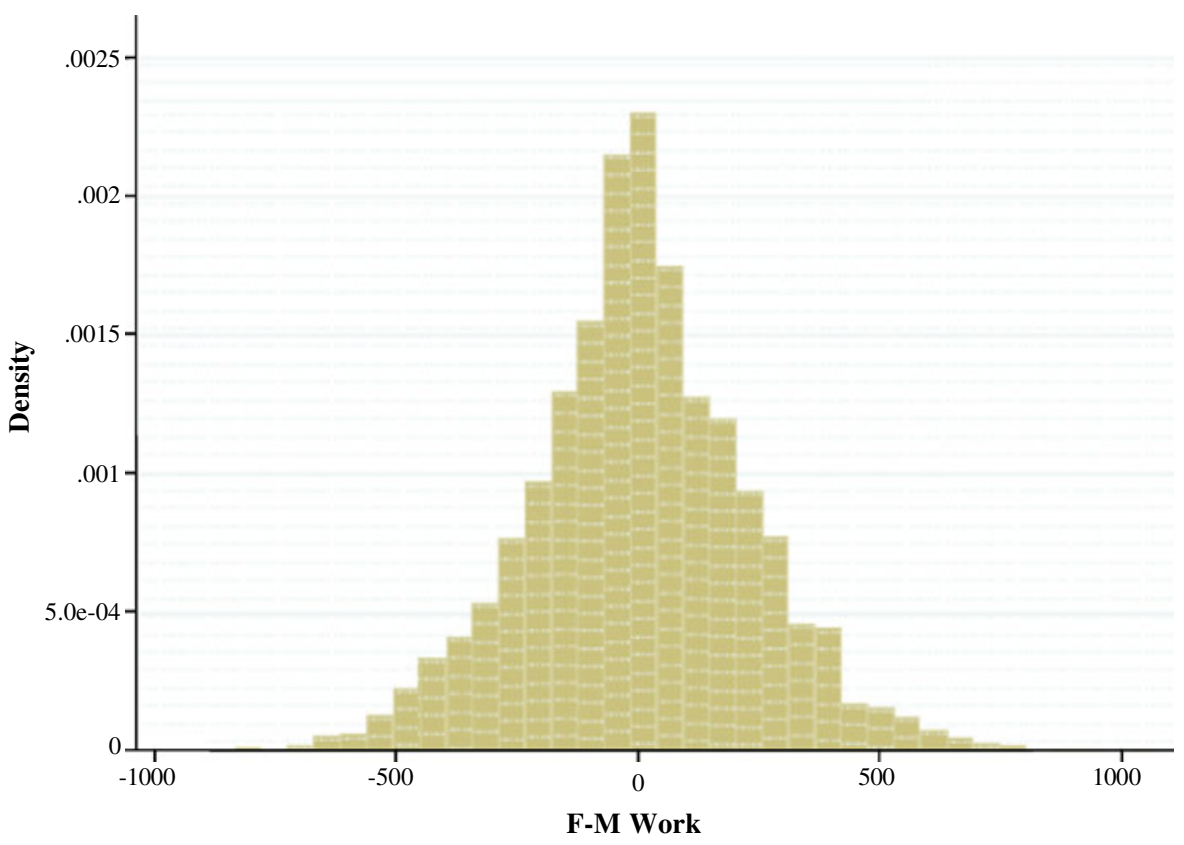

Fig. 5 Wife-husband difference in average total work per day, Germany 2001/02

correlated with income level. Then, trivially, iso-work does not hold. If genderoriented social clusters are replaced by gender-neutral reference groups as income rises (e.g., at quantiles of income distributions), development will be associated with convergence of the total work difference.

A second variant assumes that the cost of deviating from a social norm is positively related to the wage. Consider the simple one-norm model when people are harassed for deviating from the norm. Perhaps instead of suffering the direct utility loss envisaged above, deviants lose time fending off their critics, mending their reputations, or battling inner guilt feelings at the cost of time available for work or leisure. At a low wage or level of development, the weight on the norm is low, so that the intrinsic optimum is the main determinant of leisure. At a high wage or development level, the social norm becomes the sole determinant of optimal leisure. As the wage-the value of time-increases, so does the cost of deviating from the norm, resulting in a smaller deviation.

A final possibility is that there is a social stigma attached to female participation in market activities. Goldin (1995) assumes that blue-collar, but not whitecollar work by a woman entails a fixed utility loss. Imagine a simpler scenario in which any positive female market activity is stigmatized, and there is no social norm beyond this stigma. If a woman works in the market, her utility is diminished by a fixed penalty associated with the stigma, while conformity to stereotyped behavior yields positive additional utility. Staying home is 
optimal as long as the utility differential exceeds the valuation of market participation. ${ }^{13}$ Development and the concomitant rise in wages reduce the impact of gender stereotypes on behavior. In that respect, development makes men and women behave, ceteris paribus, in increasingly similar ways. ${ }^{14}$

\section{Exploring social norms as an explanation of iso-work}

An explanation based on social norms is difficult to test directly but does provide some guidelines for considering the data. Any test based on arbitrary subgroups in which the gender ratio differs is excluded by the theory. Conditioning on outcomes (e.g., examining differences by gender among paid workers) both violates the orthogonality condition and confounds effect with cause. We can, however, perform several indirect tests of the consistency of social norms with observed behavior. None of these can validate the role of social norms to the exclusion of other explanations; but each offers a chance to examine whether social norms are inconsistent with the facts presented here.

One way to examine this is to infer whether differences in attitudes about gender roles are related to international gender differences in total work. Respondents in the World Values Surveys (WVS) were asked whether they agreed with the statement, "When jobs are scarce, men should have more right to a job than women." We see this question as indicating that the society views treating men and women differently as being socially acceptable. Figure 6 presents a scatter diagram relating averages of these data for the most recent year before the time-diary survey to the female-male difference in total work for the 21 of the 27 countries used in Fig. 1 for which they are available. The scatter and the highly significant relationship between the gender total work difference and this attitudinal variable suggest that, where the expressed norm about the labor market favors men, women perform a greater share of total work. ${ }^{15}$

One might argue that this diagram merely reflects generalized cultural differences. To examine this possibility we use a general measure of attitudes

\footnotetext{
${ }^{13}$ An alternative justification for the correlation between the strength of social norms and GDP can be inferred from experimental work conducted in rural Africa (Ensminger 2004). One reason for the strength of this correlation may be that the physical demands of market work during the early stages of industrialization penalize women so that they must work more hours in order to supply the same productive effort as men.

${ }^{14}$ Of course, it might be that men exaggerate the amount of home production that they undertake in richer countries, or that women exaggerate the amount of market work that they do. Given the structure of how time diaries are collected, these seem unlikely. Moreover, additional regressions on the 27 countries depicted in Fig. 1 show absolutely no relationship between male home production and real GDP, or female market work and real GDP.

${ }^{15} \mathrm{We}$ also experimented by holding constant for average educational attainment in each country. While its inclusion did reduce the significance of the equation depicted in Fig. 6, the estimated effect was still (barely) statistically significant. Educational attainment is affected by the same cultural forces that determine these attitudes, so that its inclusion in the estimates may be incorrect.
} 


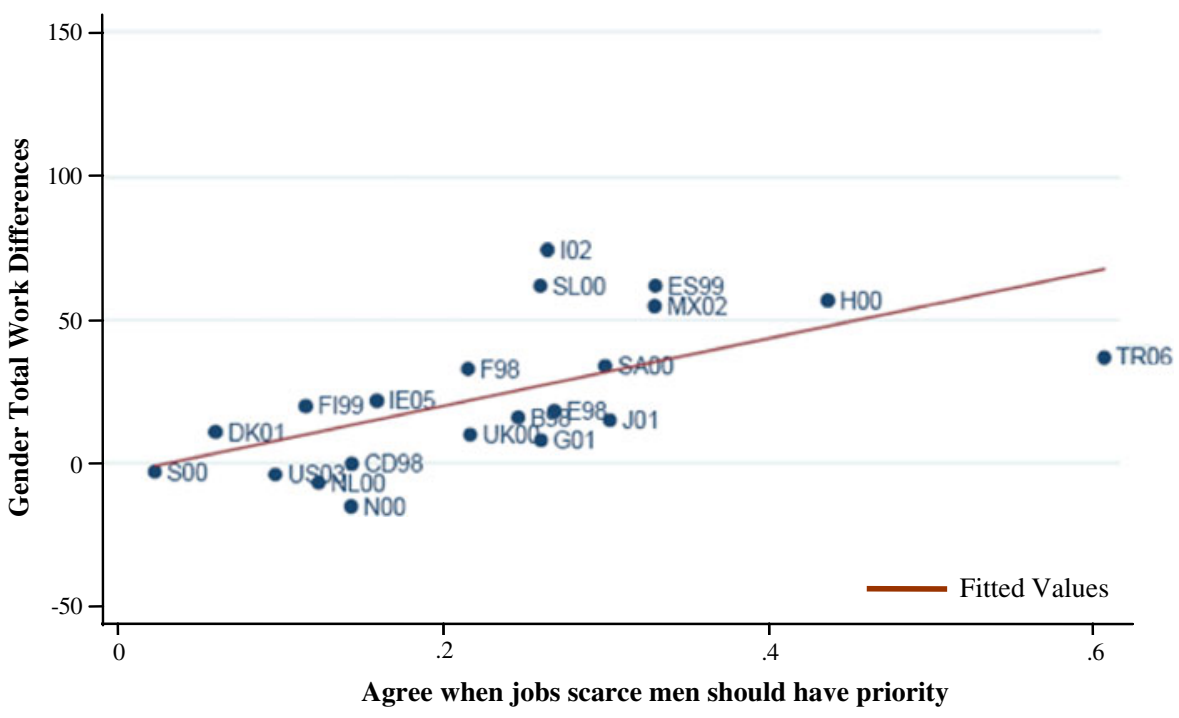

Fig. 6 Gender total work difference and attitude to job scarcity, 21 countries. DiffTotalWork $=-3.39+117.50$ (35.16) AgreeJobsMen; Adj. $R^{2}=0.337$

toward work in the WVS: the fraction of respondents agreeing that it would be unfortunate if there were less emphasis on work in the future. The scatter of this variable and the gender difference in total work by country is shown in Fig. 7, along with the regression relating the two. The fit is much worse than in Fig. 6. Taking this argument one step further, we obtained an attitudinal measure from the WVS that is unrelated to attitudes about work-the fraction of respondents stating that they are very proud of their nationality. ${ }^{16}$ The scatter and regression of this variable and the gender difference in total work in Fig. 8 show no relation between the two. ${ }^{17}$ With no claim of causation, the exercise does at least suggest a link between differences in total work and specific attitudes about gender roles in work.

Evidence on norms in this context can be gleaned from the behavior of immigrants from nearly the same set of countries for which behavior is depicted in Figs. 6-8 (see Fernández 2007). To examine this we calculate total work time using diaries from the American Time Use Survey 2003-2006. We

\footnotetext{
${ }^{16}$ All the data can be downloaded from http://www.worldvaluessurvey.com/. The second and third questions on values are: (1) "Please tell me, if it were to happen, whether you think it would be a good thing, a bad thing, or don't you mind: Less importance placed on work in our lives." (2) "How proud are you to be [Nationality]?"

${ }^{17}$ If we replace national averages of attitudes in each of these scatters with gender-specific national averages the results are hardly unchanged, as the correlations of averages of female and male attitudes in each case exceed 0.9 .
} 


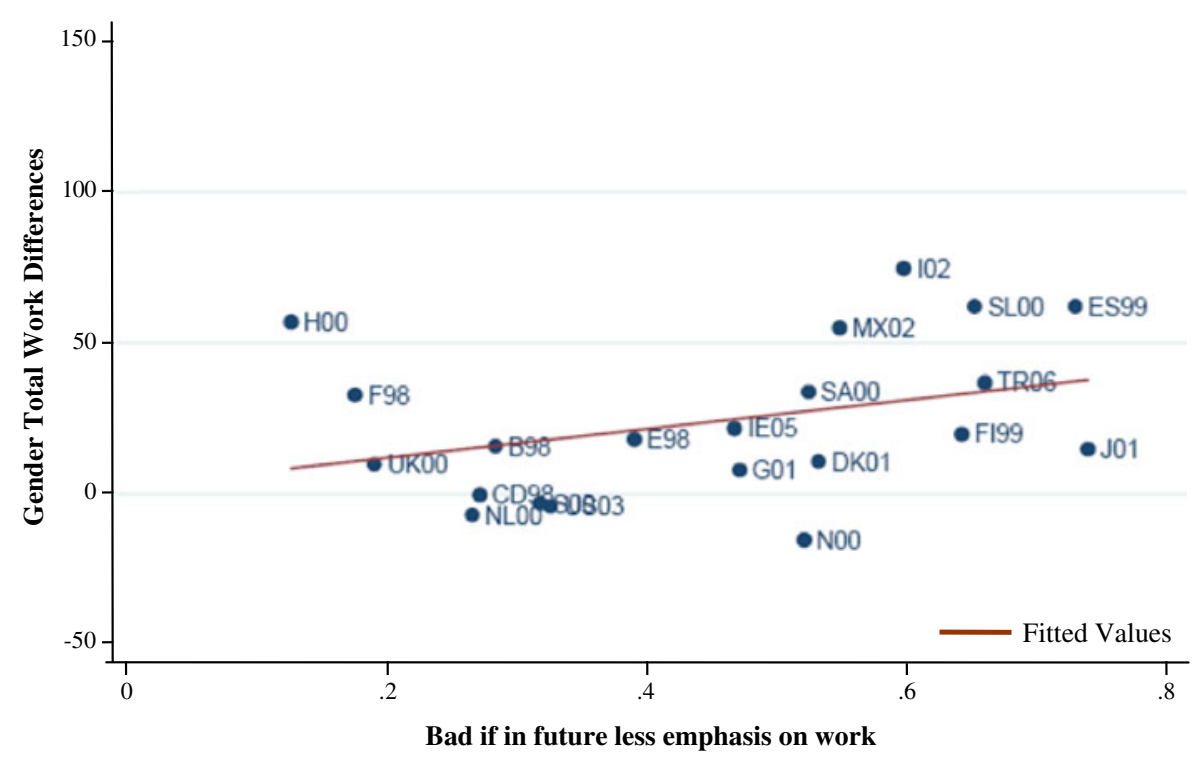

Fig. 7 Gender total work difference and attitude to value of market work, 21 countries. DiffTotalWork $=2.87+47.67$ (29.32) LessWorkBad; Adj. $R^{2}=0.078$

identified immigrants from 26 countries for which the WVS included responses to the questions used in Figs. 6-8. We then regressed average total work time on a number of demographic controls, separately for men and women. If the social norm hypothesis is not incorrect, male immigrants from those countries where people believe that men should have priorities on jobs will work less in total than other immigrants, other things equal, while women from those countries will work more. At the very least, the difference in the effect of this attitudinal measure between men and women will be negative.

The results of this estimation are shown in the first two columns of Table 3. All of the vectors of demographic variables are significant (and ignoring them does not change the estimates of the impact of the attitudinal variable on total work time). The crucial variable is not significantly different from zero, The effects are, however, of opposite sign-negative for men, positive for women, as expected; and the difference between the effects, shown in the bottom row of the Table, is significant at the $95 \%$ level in a one-sided test.

The impact of attitudes about gender roles on immigrants' work time is not small. The table also shows the range of average responses on this question in the sending countries. Using this range and the difference in the impact of this measure on work times by gender, the effect of going from the least to the most "sexist" sending country is $97 \mathrm{~min}-21 \%$ of the average total work time in this group.

The remaining two pairs of columns in Table 3 present the same specifications but with the other attitudinal variables substituted sequentially for attitudes about gender work roles. The differences between the effects of 


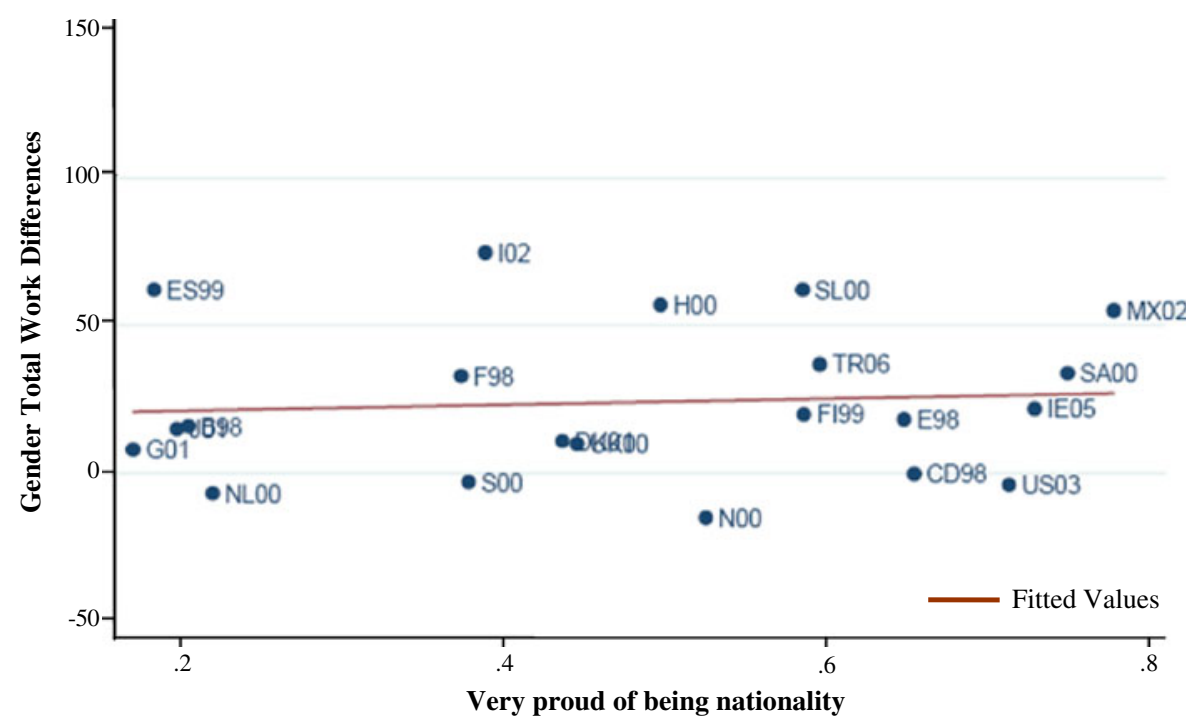

Fig. 8 Gender total work difference and pride in nationality, 21 countries. DiffTotalWork $=19.24+10.22$ (29.11) VeryProudNationality; Adj. $R^{2}=-0.046$

the attitudinal variables on total work time differences by gender are much smaller and not statistically significant (indeed, the impact of concerns about the future of work is more positive among men than among women). These results demonstrate that the estimates in Columns (1) and (2) are specifically related to attitudes about the gender and work, not to general differences in attitudes among the sending countries.

A second microeconometric examination of the possible role of social norms in affecting differences in work times by gender uses the data on couples in Australia and Germany that underlie Figs. 4 and 5 (the 1985 U.S. data have too few observations to allow forming reliable group averages that might reflect peers' behavior). For each couple (3080 in Germany, 1966 in Australia), we initially regress wife's total work on husband's, with the results shown in Columns (1) and (5) of Table 4. Following a now-substantial literature on the role of peer effects in behavior (see Borjas 1992, for an early example), in Columns (2) and (6) we add to these variables measuring the average work of wives in the particular wife's education group (four in Germany; three in Australia), age group ( $<40,40-54,55+)$ and region (West and East in Germany; New South Wales, Victoria, Queensland, and other jurisdictions in Australia). Columns (3) and (7) add controls for the wife's own demographic and family characteristics. In both countries the addition of these peer outcomes improves the ability of the equations to describe the wife's total work conditional on her husband's. Except for age for Germany in Column (3), peer outcomes of similarly-situated wives have significant impacts on the total work of individual wives. 
Table 3 Home-country social norms and immigrants' total work time, American Time Use Survey, 2003-2006

\begin{tabular}{|c|c|c|c|c|c|c|}
\hline & $\begin{array}{l}M \\
(1)\end{array}$ & $\begin{array}{l}\mathrm{F} \\
\text { (2) }\end{array}$ & $\begin{array}{l}\mathrm{M} \\
\text { (3) }\end{array}$ & $\begin{array}{l}\mathrm{F} \\
(4)\end{array}$ & $\begin{array}{l}\mathrm{M} \\
(5)\end{array}$ & $\begin{array}{l}F \\
(6)\end{array}$ \\
\hline $\begin{array}{l}\text { Agree men } \\
\text { should have } \\
\text { job priority }\end{array}$ & $\begin{array}{l}-123.16 \\
(81.23)\end{array}$ & $\begin{array}{c}46.73 \\
(70.46)\end{array}$ & & & & \\
\hline $\begin{array}{l}\text { Bad if less } \\
\text { emphasis on work }\end{array}$ & & & $\begin{array}{c}54.44 \\
(77.02)\end{array}$ & $\begin{array}{l}-11.41 \\
(58.86)\end{array}$ & & \\
\hline Very proud of nationality & & & & & $\begin{array}{l}-26.01 \\
(59.22)\end{array}$ & $\begin{array}{l}-6.49 \\
(44.34)\end{array}$ \\
\hline Schooling: & & & & & & \\
\hline 12 years & $\begin{array}{c}38.67 \\
(29.21)\end{array}$ & $\begin{array}{l}-1.68 \\
(23.02)\end{array}$ & & & & \\
\hline $13-15$ years & $\begin{array}{c}24.03 \\
(31.38)\end{array}$ & $\begin{array}{l}-19.61 \\
(23.48)\end{array}$ & & & & \\
\hline $16+$ years & $\begin{array}{c}64.32 \\
(26.01)\end{array}$ & $\begin{array}{c}9.41 \\
(22.46)\end{array}$ & & & & \\
\hline Age & $\begin{array}{l}23.70 \\
(7.73)\end{array}$ & $\begin{array}{l}23.30 \\
(6.16)\end{array}$ & & & & \\
\hline $\mathrm{Age}^{2} / 100$ & $\begin{array}{l}-30.20 \\
(9.61)\end{array}$ & $\begin{array}{l}26.21 \\
(7.86)\end{array}$ & & & & \\
\hline Married & $\begin{array}{l}59.65 \\
(22.27)\end{array}$ & $\begin{array}{c}26.46 \\
(17.75)\end{array}$ & & & & \\
\hline Adj. $R^{2}$ & 0.0435 & 0.0351 & 0.0412 & 0.0345 & 0.0408 & 0.0345 \\
\hline$N$ & 659 & 763 & 659 & 763 & 659 & 763 \\
\hline $\begin{array}{l}\text { Range of } \\
\text { attitudinal variable }\end{array}$ & \multicolumn{2}{|c|}{$[0.125,0.694]$} & \multicolumn{2}{|c|}{$[0.065,0.719]$} & \multicolumn{2}{|c|}{$[0.138,0.895]$} \\
\hline $\begin{array}{l}\text { Difference in } \\
\text { effects of } \\
\text { attitudinal variables }\end{array}$ & \multicolumn{2}{|c|}{$\begin{array}{l}-169.89 \\
(107.53)\end{array}$} & \multicolumn{2}{|c|}{$\begin{array}{c}65.85 \\
(96.94)\end{array}$} & \multicolumn{2}{|c|}{$\begin{array}{l}-19.52 \\
(73.98)\end{array}$} \\
\hline
\end{tabular}

Robust standard errors in parentheses beneath parameter estimates, standard error beneath the differences in effects of the attitudinal variables. Columns (3)-(6) include the same controls as in Columns (1) and (2)

One might argue that these results merely reflect the reflection problem by Manski (1995). We cannot demonstrate causation conclusively, but indirect evidence suggests that our results do not arise solely from the reflection of one's own behavior. One solution partitions the German and Australian samples into halves, calculates peer averages for one half-sample and includes them in regressions like those in Columns (3) and (6) based only on the other half-sample. The results of re-estimating the equations on the second halfsamples differ little from those shown in the Table. These similar results cannot be based on reflections, as the half-samples are different.

Individuals in the half-samples may, however, be responding to their own unmeasured common characteristics rather than to the behavior of their peers. There is no way of circumventing this potential difficulty completely, just as in the larger peer-effects literature extricating common effects from responses to peers' outcomes is exceedingly difficult. In the case of Germany, however, we can probe a bit further by including in the regressions describing wives in 
Table 4 Effects of social norms, married couples, Germany 2001/02, Australia 1992

\begin{tabular}{|c|c|c|c|c|c|c|c|}
\hline \multirow{2}{*}{$\begin{array}{l}\text { Dep. var.: } \\
\text { Wife's total work }\end{array}$} & \multicolumn{4}{|c|}{ Germany } & \multicolumn{3}{|c|}{ Australia } \\
\hline & (1) & (2) & (3) & (4) & (5) & (6) & (7) \\
\hline $\begin{array}{l}\text { Husband's } \\
\text { total work }\end{array}$ & $\begin{array}{c}0.491 \\
(0.012)\end{array}$ & $\begin{array}{c}0.441 \\
(0.013)\end{array}$ & $\begin{array}{c}0.432 \\
(0.013)\end{array}$ & $\begin{array}{c}0.447 \\
(0.013)\end{array}$ & $\begin{array}{c}0.416 \\
(0.015)\end{array}$ & $\begin{array}{c}0.358 \\
(0.016)\end{array}$ & $\begin{array}{c}0.355 \\
(0.016)\end{array}$ \\
\hline $\begin{array}{l}\text { Total work } \\
\text { in wife's } \\
\text { education group }\end{array}$ & & $\begin{array}{c}0.298 \\
(0.081)\end{array}$ & $\begin{array}{c}0.252 \\
(0.075)\end{array}$ & $\begin{array}{l}-0.404 \\
(0.231)\end{array}$ & & $\begin{array}{c}0.466 \\
(0.111)\end{array}$ & $\begin{array}{c}0.587 \\
(0.129)\end{array}$ \\
\hline Age group & & $\begin{array}{c}0.281 \\
(0.046)\end{array}$ & $\begin{array}{c}0.055 \\
(0.065)\end{array}$ & $\begin{array}{c}0.216 \\
(0.033)\end{array}$ & & $\begin{array}{c}0.431 \\
(0.056)\end{array}$ & $\begin{array}{c}0.231 \\
(0.070)\end{array}$ \\
\hline Region & & $\begin{array}{c}0.722 \\
(0.159)\end{array}$ & $\begin{array}{c}0.873 \\
(0.161)\end{array}$ & $\begin{array}{c}0.443 \\
(0.098)\end{array}$ & & $\begin{array}{c}1.276 \\
(0.518)\end{array}$ & $\begin{array}{l}1.668 \\
(0.812)\end{array}$ \\
\hline $\begin{array}{l}\text { Norm used } \\
\text { Wife's education, age }\end{array}$ & & Current & $\begin{array}{c}\text { Current } \\
\text { Yes }\end{array}$ & Lagged & & Current & $\begin{array}{c}\text { Current } \\
\text { Yes }\end{array}$ \\
\hline $\begin{array}{l}\text { Number and } \\
\text { ages of children }\end{array}$ & & & Yes & & & & Yes \\
\hline $\begin{array}{l}\text { Adj. } R^{2} \\
N\end{array}$ & 0.353 & 0.372 & $0^{0.377}$ & 0.368 & 0.292 & $\begin{array}{l}0.325 \\
1966\end{array}$ & 0.336 \\
\hline
\end{tabular}

Standard errors in parentheses. In Germany total work is averaged over 3 days, in Australia it is averaged over two days. For both countries the age groups are under 40, 40-54 and 55+. There are four education groups in Germany, three in Australia. Germany is divided into West and East, Australia into New South Wales, Victoria, Queensland and other jurisdictions

2001/02 peer outcomes based on wives included in a nearly identical survey in 1991/92. Those results are presented in Column (4) of Table 4 and should be compared to the results in Column (2). While the impact of wives' peers' education is attenuated when we include lagged values, the impacts of peer outcomes in the same age group and region, although weaker, are still highly significant statistically.

\section{Conclusion: implications for economic modeling}

We have presented evidence suggesting that men's and women's total work in a large group of rich countries does not differ significantly and have dubbed this apparent phenomenon "iso-work." This phenomenon has been hinted at but glossed over by a few sociologists but does not appear to have entered into the conventional wisdom held by economists, sociologists or the public. It could be important for modeling in a variety of areas of economics, and we have attempted to explore one of the many potential explanations for it, namely the idea of social norms. Whether that explanation is the best one is unclear; but the difficulty accounting for the results with conventional, neoclassical economic theory is suggestive of the value of models with social interactions. Our exploration sheds light on what might be required to explain the apparent iso-work phenomenon.

The first implication of our findings and attempts at explanation is linked to economic development. Our evidence documents convergence of total work 
across gender with GDP per-capita. We show in Section 4 that this convergence can derive either from increasingly gender-blind assignment to reference clusters with strong norms, or from a convergence of gender wage-offer distributions to a common one. The past half century has also seen secular, albeit slow convergence in gender wage differentials. These two phenomena are probably related, but what is their source? Has technical change augmented female market production relative to that of men? Is technical change in home production generally labor-saving (see Greenwood et al. 2005)? How have interactions of these two types of innovation combined to generate convergence in total work and the returns to market work? Examining these interactions without considering gender roles (e.g., Ngai and Pissarides 2008) is a useful step; but given the significant differences in gender roles in less developed countries, understanding growth and development requires accounting better for the convergence of total work and changes in the relative amounts of market and household work performed by men and women. This is especially true considering the different roles played by physical and intellectual attributes during economic development (Clark 1940).

Second, household models typically assume that a spouse's bargaining power is a function of her/his market earnings. Yet we have shown here, at least for most rich economies, that gender differences in the amounts of non-work time are tiny. How can this be true if, as is still the case, men have substantially higher wage rates and market earnings? Three logical possibilities present themselves. Men have more power, but are altruistic toward their spouses and toward women generally, and do not take advantage of it. ${ }^{18}$ Another is that economists' modeling of the household has been incorrect, and market earnings do not generate power in the household. A final alternative is that earnings do generate power, men are not altruistic, but the average man's utility from his market and home work exceeds that of the average woman's from the same total amount of work. This last possibility would formalize ideas of the few sociologists who have confronted the issue (e.g., Mattingly and Bianchi 2003). Yet this possibility shifts the discussion to why women find their work more onerous than men find theirs. Why, e.g., is the marginal minute spent in an office dealing with recalcitrant colleagues and supervisors more pleasurable than the marginal minute spent baking a cake?

Our results suggest the potential importance of going beyond standard neoclassical models to analyze social phenomena. Our inability to use neoclassical models to predict the patterns and correlates that we have demonstrated and their apparent consistency with some implications of some models of social norms suggest that this may be a fruitful approach to the study of labor markets generally.

\footnotetext{
${ }^{18}$ Doepke and Tertilt (2009) present a model in which self-interest motivated by inter-generational concerns leads men to use their power to grant equal rights to women. Bertocchi (2011) constructs a model in which concerns by a changing median voter lead to extensions of rights to women.
} 
Open Access This article is distributed under the terms of the Creative Commons Attribution Noncommercial License which permits any noncommercial use, distribution, and reproduction in any medium, provided the original author(s) and source are credited.

\section{DATA APPENDIX: Definitions of Total Work in 27 Countries}

United States(US): Market work and work-related activities; travel related to work; all household activities; caring for and helping household members; consumer purchases; professional and personal care services; household services; government services; travel related to these.

Australia(AUS): Market work; cleaning and cooking; family and child care; shopping; and travel associated with each.

Belgium(B), Denmark(DK), France(F), Finland(FI), Sweden(S), United King$\operatorname{dom}(U K)$, Estonia(ES), Hungary(H), Slovenia(SL), Norway(N): Gainful work; study; household work + family care; proratio of travel time based on gainful work time.

Benin(BEN), Madagascar(MAD), Mauritius(MAU), South Africa(SA): Market work; domestic and care activities; commuting.

Canada $(C D)$ ): "Total work" (paid work and related activities; unpaid work and related activities).

Germany $(G)$ : Market work: employment and job search; home work activities; handicraft/gardening; care and sitting.

Ireland(IE): Care; employment and study; household work; proratio of travel time based on gainful work time.

Israel(IL): Market work; cooking and cleaning at home; child care.

Italy(I): Market work; professional activities; training; domestic activities; family care; purchasing goods and services.

$\operatorname{Japan}(J)$ : Work, school work; house work, caring or nursing, child care, shopping.

Mexico $(M X)$ : Domestic work; care of children and other household members; market work.

Netherlands(NL): Occupational work and related travel; household work, do-it yourself, gardening, etc; childcare; shopping. 
New Zealand(NZ): Paid work; household work, care-giving for household members, purchasing goods or services, unpaid work for people outside the home.

$\operatorname{Spain}(E)$ : Market work; house work, child care, adult care.

Turkey(TR): Employment and job seeking; study; household and family care; proratio of travel time based on gainful work time.

\section{References}

Akerlof G (1980) A theory of social custom, of which unemployment may be one consequence. Q J Econ 94(2):749-775

Aliaga C, Winqvist K (2003) How women and men spend their time. Statistics in focus: population and social conditions. Eurostat, Luxembourg

Bernheim BD (1994) The economics of conformity. J Polit Econ 102(5):841-877

Bertocchi G (2011) The enfranchisement of women and the welfare state. Eur Econ Rev 55(4):535-553

Biddle J, Hamermesh D (1990) Sleep and the allocation of time. J Polit Econ 98(5):922-943

Bittman M, Wacjman J (2000) The rush hour: the character of leisure time and gender equity. Soc Forces 79(1):165-189

Blackden CM, Wooden Q (2006) Gender, time use, and poverty in sub-Saharan Africa. World Bank, Washington

Borjas G (1992) Ethnic capital and intergenerational mobility. Q J Econ 107(1):123-150

Burda M, Hamermesh D, Weil P (2007) Total work, gender and social norms. NBER Working Paper No. 13000

Cigno A (2009) What's the use of marriage? IZA Discussion Paper No. 4635

Clark C (1940) The conditions of economic progress. Macmillan, London

Doepke M, Tertilt M (2009) Women's liberation: what's in it for men? Q J Econ 124(4):1541-1591

Ensminger J (2004) Market integration and fairness: evidence from ultimatum, dictator, and public goods experiments in East Africa. In: Henrich J, Boyd R, Bowles S, Camerer C, Fehr E, Gintis $\mathrm{H}$ (eds) Foundations of human sociality: economic experiments and ethnographic evidence from fifteen small-scale societies. Oxford University, Oxford, pp 356-381

Fernández R (2007) Women, work and culture. J Eur Econ Assoc 5(2):305-333

Fernández R (2010) Does culture matter? In: Benhabib J, Bisin A, Jackson M (eds) Handbook of social economics, vol 1a. Elsevier, Amsterdam, pp 481-510

Freeman R, Schettkat R (2005) Marketization of household production and the EU-US Gap in work. Econ Policy 20(1):6-50

Gershuny J (2000) Changing times: work and leisure in postindustrial society. Oxford University, Oxford

Goldin C (1995) The U-shaped female labor force participation function in economic development and economic history. In: Schultz TP (ed) Investment in women's human capital and economic development. University of Chicago, Chicago, pp 61-90

Greenwood J, Seshadri A, Yorukoglu M (2005) Engines of liberation. Rev Econ Stud 72(1):109_ 133

Hamermesh D (2002) Timing, togetherness and time windfalls. J Popul Econ 15(4):601-623

Heston A, Summers R, Aten B (2006) Penn World Tables Versions 6.1, 6.2. Center for International Comparisons of the University of Pennsylvania, Philadelphia

Hochschild AR (1997) The time bind. Holt, New York

Kalenkoski C, Ribar D, Stratton L (2009) The influence of wages on parents' allocations of time to child care and market work in the United Kingdom. J Popul Econ 22(2):399-419

Knowles J (2011) Why are married men working so much? Relative wages, labor supply and the decline of marriage. Bonn, DE, Institute for the Study of Labor, 58 pp. IZA Working Paper Series 
Kooreman P (2007) Time, money, peers and parents: some data and theories on teenage behavior. J Popul Econ 20(1):9-33

Lindbeck A, Nyberg S, Weibull J (1999) Social norms and economic incentives in the welfare state. Q J Econ 114(1):1-35

Lundberg S, Pollak R (1996) Bargaining and distribution in marriage. J Econ Perspect 10(4):139_ 158

Manski C (1995) Identification problems in the social sciences. Harvard University, Cambridge

Mattingly M, Bianchi S (2003) Gender differences in the quantity and quality of free time. Soc Forces 81(3):999-1030

Ngai LR, Pissarides C (2008) Trends in hours and economic growth. Rev Econ Dyn 11(2):239-256

Polachek S, Xiang J (2009) The gender pay gap across countries: a human capital approach. DIWBerlin, SOEP Paper Number 227

Reid M (1934) Economics of household production. Wiley, New York

Robinson J, Godbey G (1999) Time for life: the surprising ways Americans use their time, 2nd edn. University Park, PA: Pennsylvania State University, University Park 